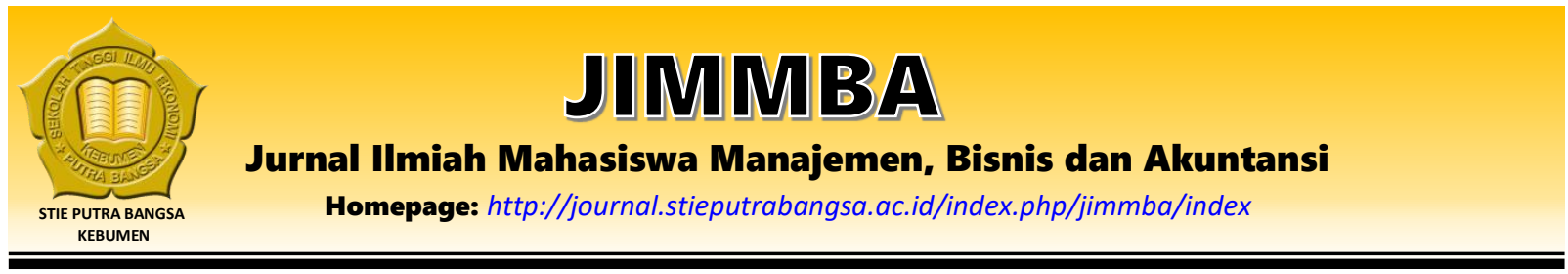

\title{
Analisis Pengaruh Kualitas Pelayanan, Harga, dan Lokasi Terhadap Kepuasan Konsumen pada Warung Bakso Lumayan Pak Cipto Karanganyar
}

\author{
Aditya Nugroho', Prihartini Budi Astuti ${ }^{2}$ \\ 1,2 Universitas Putra Bangsa \\ soekotjo27@gmail.com ${ }^{1}$
}

\section{ARTICLE INFO}

Article History:

Received: September $18^{\text {th }} 2021$

Accepted: September $9^{\text {th }} 2021$

Published: October $9^{\text {th }} 2021$

Keywords:

Kualitas Pelayanan, Harga,

Lokasi, Kepuasan Konsumen

\begin{abstract}
Penelitian ini bertujuan untuk mengetahui seberapa besar pengaruh kualitas pelayanan, harga dan lokasi terhadap kepuasan konsumen pada Warung Bakso Lumayan Pak Cipto Karanganyar. Pengambilan sampel pada penelitian ini menggunakan probability sampling dengan teknik random sampling dengan jumlah sampel sebanyak 100 responden. Dengan menggunakan analisis regresi linear berganda. Hasil dari penelitian ini menyimpulkan bahwa kualitas pelayanan, harga dan lokasi melalui uji hipotesis dua arah berpengaruh signifikan terhadap kepuasan konsumen pada Warung Bakso Lumayan Pak Cipto Karanganyar. Sementara itu, melalui uji simultan didapatkan bahwa kualitas pelayanan, harga dan lokasi secara bersama-sama berpengaruh signifikan terhadap kepuasan konsumen pada Warung Bakso Lumayan Pak Cipto Karanganyar. Hasil penelitian ini memberikan implikasi bahwa faktor kualitas pelayanan, harga dan lokasi adalah variabel yang perlu dipertahankan dan ditingkatkan untuk meningkatkan kepuasan konsumen pada Warung Bakso Lumayan Pak Cipto Karanganyar.
\end{abstract}

\section{Pendahuluan}

Berkembangnya dunia usaha mewajibkan perusahaan untuk selalu melakukan perbaikan terhadap cara perusahaan melayani konsumen, memberikan fasilitas dan strategi dalam menghadapi persaingan. Banyaknya perusahaan yang menawarkan produk atau jasa membuat para konsumen memiliki banyak pilihan produk dan jasa sesuai dengan keinginan dan kebutuhan mereka, dalam hal ini setiap perusahaan harus mampu menyediakan produk yang terbaik dan memberikan pelayanan yang sesuai dengan kebutuhan dan keinginan konsumen. Faktor yang harus diperhatikan apabila perusahaan ingin semakin berkembang adalah dengan menjalin hubungan baik dengan pelanggan yang ada, jangan sampai pelanggan tersebut meninggalkan produk satu dan beralih ke produk lain.

Konsumen sebagai penikmat kuliner tentunya akan mempertimbangkan aspek kualitas pelayanan, harga, dan lokasi pada rumah makan yang disediakan oleh rumah makan yang sesuai dengan yang diharapkan pelanggan, sehingga setelah konsumen merasa puas dengan apa yang konsumen harapkan, pelanggan akan merekomendasikan ke orang lain dan minat untuk membeli ulang kembali. Usaha kuliner Warung Bakso Lumayan Pak Cipto 
menyajikan menu makanan kuliner bakso \& soto sebagai salah satu produk makanan kuliner dengan kualitas produk dan cita rasa yang cukup memuaskan. Warung Bakso Lumayan Pak Cipto merupakan salah satu usaha kuliner yang memiliki keunggulan dengan cita rasa yang diinginkan oleh konsumen.

Warung Bakso Lumayan Pak Cipto adalah sebuah warung bakso yang terletak di daerah Karanganyar Kabupaten Kebumen dengan desaign yang baik di lengkapi dengan tempat yang sejuk dan nyaman serta didukung dengan fasilitas TV dan kipas angin sehingga konsumen bisa merasakan kenyamanan tersendiri. Rumah makan ini menyajikan menu makanan bakso, soto, serta makanan ringan sebagai pelengkap dan berbagai macam minuman. Banyak sekali faktor yang membuat warung Bakso Lumayan Pak Cipto menjadi salah satu tempat yang layak untuk dikunjungi.

Sebagai pelaku bisnis harus mampu memahami perilaku konsumen pada sasaran pasarnya, hal itu karena kelangsungan hidup bisnis sangat dipengaruhi oleh perilaku konsumen. Perilaku konsumen merupakan tindakan individu dalam memperoleh, menggunakan, dan menentukan produk untuk memenuhi kebutuhannya. Menurut Tjiptono dalam (Anna Fitria dan Imam Hidayat, 2017: 2), strategi pemasaran merupakan alat yang direncanakan dalam kegiatan pemasaran untuk memanfaatkan peluang yang ada dan mengungguli pesaingnya.

Kepuasan konsumen didefinisikan sebagai tingkat perasaan seseorang setelah membandingkan kinerja atau hasil yang dia rasakan dibandingkan dengan harapannya Kotler dan Keller dalam donni juni priansah (2017: 196).

Kepuasan konsumen di Warung Bakso Lumayan Pak Cipto Karanganyar dapat dipengaruhi oleh beberapa faktor. Untuk mengetahui hal diatas, maka peneliti melakukan mini riset terhadap 35 responden melalui wawancara.

Tabel 1. Hasil Wawancara

\begin{tabular}{lcc}
\hline Variabel & $\begin{array}{c}\text { Jumlah } \\
\text { (Orang) }\end{array}$ & $\begin{array}{c}\text { Presentase } \\
\text { (\%) }\end{array}$ \\
\hline Kualitas pelayanan & 15 & $43 \%$ \\
Harga & 10 & $29 \%$ \\
Lokasi & 5 & $14 \%$ \\
Kualitas produk & 5 & $14 \%$ \\
\hline
\end{tabular}

Sumber: Survey Lapangan (2021)

Berdasarkan tabel hasil wawancara di atas dapat disimpulkan bahwa Faktor yang paling dominan mempengaruhi kepuasan konsumen adalah kualitas pelayanan. Menurut Fandy Tjiptono (2014 : 268) definisi kualitas pelayanan berfokus pada upaya pemenuhan kebutuhan dan keinginan konsumen serta ketepatan penyampaianya untuk mengimbangi harapan konsumen. Salah satu faktor yang mempengaruhi kepuasan konsumen yaitu kualitas pelayanan, pendapat tersebut didasari oleh hasil penelitian yang dilakukan oleh Tiyas Windarti dan Mariaty Ibrahim (2017) pada penelitiannya yang berjudul "Pengaruh Kualitas Produk dan Kualitas Pelayanan terhadap Kepuasan Konsumen Produk Donut Madu Cihanjuang Pekanbaru".

Selanjutnya, faktor yang mempengaruhi kepuasan konsumen adalah harga. Menurut Kotler dan Armstrong (2001: 439) harga adalah sejumlah uang yang dibebankan atas suatu produk atau jasa, atau jumlah dari nilai yang ditukar konsumen atas manfaat-manfaat karena memiliki atau menggunakan produk atau jasa tersebut. Menurut Yulisetiarini Diah (2013 dan 2018) harga berpengaruh pada kepuasan konsumen, hal ini menyiratkan bahwa harga sama dengan apa yang diharapkan oleh konsumen. Harga yang ditetapkan harus sesuai dengan perekonomian konsumen, agar konsumen dapat membeli barang tersebut. 
Sedangkan bagi konsumen, harga merupakan bahan pertimbangan dalam mengambil keputusan pembelian. Salah satu faktor yang dapat mempengaruhi kepuasan konsumen yaitu harga pendapat tersebut didasari hasil penelitian yang dilakukan oleh Indah ayu lestari (2015) pada penelitian yang berjudul "Pengaruh harga dan kualitas pelayanan terhadap kepuasan konsumen klinik Erhaskin Cirebon".

Faktor yang tidak kalah penting adalah faktor lokasi usaha. menurut Sunyoto (2015:176), Lokasi diartikan sebagai lokasi yang strategis dimana banyak calon pembeli, dalam artian lokasi ini mudah dijangkau, mudah dilihat konsumen dan lokasi yang banyak dilalui dan dihuni target konsumen yang berpotensi membeli produk atau jasa yang dijual. Lokasi yang mudah dijangkau oleh konsumen dan dekat dengan pusat keramaian merupakan lokasi yang tepat untuk suatu usaha, termasuk usaha warung makan. Salah satu faktor yang dapat mempengaruhi kepuasan konsumen yaitu lokasi, pendapat tersebut didasari oleh hasil penelitian yang dilakukan oleh Wulandari (2013).

\section{Kajian Teori dan Telaah Literatur}

\section{Kepuasan Konsumen}

Kepuasan konsumen didefinisikan sebagai tingkat perasaan seseorang setelah membandingkan kinerja atau hasil yang dia rasakan dibandingkan dengan harapannya Kotler dan Keller dalam donni juni priansah (2017: 196). Perbandingan antara harapan dan kinerja tersebut akan menghasilkan perasaan senang atau kecewa di benak pelanggan. Menurut Hawkins dan Lonney dikutip dalam Tjiptono (2014 : 101) indikator pembentuk kepuasan konsumen terdiri dari:
a. Kesesuaian Harapan
Merupakan tingkat kesesuaian antara kinerja jasa yang diharapkan oleh konsumen dengan yang dirasakan oleh konsumen.
b. Minat Berkunjung Kembali
Merupakan kesediaan konsumen untuk berkunjung kembali atau melakukan pemakaian ulang terhadap jasa terkait.

\section{c. Kesediaan Merekomendasi dirasakan kepada teman atau keluarga.}
Merupakan kesediaan konsumen untuk merekomendasikan jasa yang telah

\section{Kualitas Pelayanan}

Kualitas pelayanan menurut Ibrahim dalam Hardiyansyah (2011) merupakan suatu kondisi dinamis yang berhubungan dengan produk, jasa,manusia, proses, dan lingkungan dimana penilaian kualitasnya ditentukan pada saat terjadinya pemberian pelayanan publik tersebut Menurut Parasuraman, et al dalam Tjiptono (2005 : 288) menyatakan atribut yang dapat digunakan untuk mengevaluasi kualitas pelayanan dapat dilihat dari lima dimensi pokok, yaitu:
a. Responsiveness (daya tanggap)
b. Reliability (kehandalan)
c. Assurance (jaminan dan kepastian)
d. Empathy (empati)
e. Tangibles (bukti fisik)

\section{Harga}

Harga Menurut Alma (2011:169), adalah satuan moneter atau ukuran lainnya termasuk barang dan jasa lainnya yang ditukarkan agar memperoleh hak kepimilikan atau pengguna 
suatu barang dan jasa sehingga menimbulkan kepuasan konsumen. Menurut Kotler dan Amstrong terjemahan Sabran (2012:278), ada 4 indikator yang mencirikan harga, yaitu:
a. Keterjangkauan harga
b. Kesesuaian harga dengan kualitas produk
c. Daya saing harga
d. Kesesuaian harga dengan manfaat

\section{Lokasi}

Menurut Heizer \& Render (2015) lokasi adalah pendorong biaya dan pendapatan, maka lokasi seringkali memiliki kekuasaannya untuk membuat strategi bisnis perusahaan. Lokasi yang strategis bertujuan untuk memaksimalkan keuntungan dari lokasi perusahaan. Faktor penting dalam pengembangan suatu usaha adalah letak lokasi terhadap daerah perkotaan, cara pencapaian dan waktu tempuh lokasi ke tujuan. Faktor lokasi yang baik adalah relatif untuk setiap jenis usaha yang berbeda. Lokasi menurut Aprih Santoso dan Sri Yuni Widowati (dalam Gugun,2015:16) dapat didefinisikan sebagai tempat untuk melaksanakan kegiatan atau usaha sehari-hari. Indikator dari variabel lokasi adalah sebagai berikut:

a. Keterjangkauan.

b. Kelancaran.

c. Kedekatan dengan kediamannya.

\section{Hipotesis}

$\mathbf{H}_{1}$ : Kualitas pelayanan berpengaruh signifikan terhadap kepuasan konsumen Warung Bakso Lumayan Pak Cipto Karanganyar

$\mathbf{H}_{2}$ : Harga berpengaruh signifikan terhadap kepuasan konsumen Warung Bakso Lumayan Pak Cipto Karanganyar

$\mathbf{H}_{3}$ : Lokasi berpengaruh signifikan terhadap kepuasan konsumen Warung Bakso Lumayan Pak Cipto Karanganyar

$\mathbf{H}_{4}$ : Kualitas pelayanan, harga, dan lokasi secara simultan berpengaruh signifikan terhadap kepuasan konsumen Warung Bakso Lumayan Pak Cipto Karanganyar

\section{Metode Penelitian}

\section{Objek dan Subjek Penelitian}

Obyek penelitian ini adalah kualitas pelayanan, harga, lokasi, dan kepuasan konsumen. Sementara subyek penelitian adalah konsumen Warung Bakso Lumayan Pak Cipto Karanganyar.

\section{Teknik Pengambilan Sampel}

Metode pemilihan sampel yang digunakan adalah random sampling/probability sampling. Menurut Sugiyono (2017:82) probability sampling adalah teknik pengambilan sampel yang memberikan peluang atau kesempatan yang sama bagi setiap unsur atau anggota populasi untuk dipilih menjadi sampel. Alasan penggunaan metode tersebut dikarenakan peneliti ingin mendapatkan informasi yang tepat dengan cara yang praktis (populasi yang banyak dan dilakukan secara acak tanpa memperhatikan strata yang ada dalam populasi itu). Dengan demikian sampel yang digunakan untuk responden dalam penelitian ini berjumlah 100 orang, hal ini dilakukan untuk berjaga-jaga terhadap kemungkinan adanya resiko nilai minimum yang akan didapat. 


\section{Alat Analisis Data}

Instrumen yang digunakan untuk memperolah data yaitu dengan menggunakan kuesioner atau angket. Metode penelitian yang digunakan adalah teknik analisis regresi linear berganda yang harus memenuhi uji asumsi klasik. Uji hipotesis yang dilakukan menggunakan uji $\mathrm{t}$ dan uji $\mathrm{F}$, dan koefisien determinasi dengan bantuan program SPSS for Windows version 25.0.

\section{Hasil dan Pembahasan}

\section{Uji Validitas dan Reliabilitas}

Suatu kuesioner dapat dikatakan valid apabila pernyataan pada kuesioner mampu untuk mengungkapkan sesuatu yang akan diukur oleh kuesioner tersebut. Sebuah data dikatakan valid apabila nilai signifikansi $<0,05$, dan jika $r_{\text {hitung }}>r_{\text {tabel. }}$. Data dapat dikatakan reliabel jika nilai alpha cronbach $>0,60$ atau $60 \%$.

Tabel 2. Hasil Uji Validitas Variabel Kualitas Pelayanan

\begin{tabular}{ccccc}
\hline Butir & $\mathbf{r}_{\text {hitung }}$ & $\mathbf{r}_{\text {tabel }}$ & Signifikansi & Keterangan \\
\hline X1.1 & 0,772 & 0,1966 & 0,000 & Valid \\
X1.2 & 0,847 & 0,1966 & 0,000 & Valid \\
X1.3 & 0,827 & 0,1966 & 0,000 & Valid \\
X1.4 & 0,820 & 0,1966 & 0,000 & Valid \\
X1.5 & 0,623 & 0,1966 & 0,000 & Valid \\
\hline
\end{tabular}

Sumber: Data primer diolah (2021)

Berdasarkan tabel 2 di atas menunjukkan item instrumen variabel kualitas pelayanan (X1) dinyatakan valid karena $r_{\text {hitung }}>r_{\text {tabel }}$ dan nilai signifikansi $<0,05$ sehingga semua item yang dipakai pada variabel kualitas pelayanan (X1) dinyatakan valid (sah).

Tabel 3. Hasil Uji Validitas Variabel Harga

\begin{tabular}{ccccc}
\hline Butir & $\mathbf{r}_{\text {hitung }}$ & $\mathbf{r}_{\text {tabel }}$ & Signifikansi & Keterangan \\
\hline X2.1 & 0,784 & 0,1966 & 0,000 & Valid \\
X2.2 & 0,687 & 0,1966 & 0,000 & Valid \\
X2.3 & 0,602 & 0,1966 & 0,000 & Valid \\
X2.4 & 0,586 & 0,1966 & 0,000 & Valid
\end{tabular}

Sumber: Data primer diolah (2021)

Berdasarkan tabel 3 di atas menunjukkan item instrumen variabel harga (X2) dinyatakan valid karena $r_{\text {hitung }}>r_{\text {tabel }}$ dan nilai signifikansi $<0,05$ sehingga semua item yang dipakai pada variabel harga (X2) dinyatakan valid (sah).

Tabel 4. Hasil Uji Validitas Variabel Lokasi

\begin{tabular}{ccccc}
\hline Butir & $\mathbf{r}_{\text {hitung }}$ & $\mathbf{r}_{\text {tabel }}$ & Signifikansi & Keterangan \\
\hline X3.1 & 0,862 & 0,1966 & 0,000 & Valid \\
X3.2 & 0,839 & 0,1966 & 0,000 & Valid \\
X3.3 & 0,516 & 0,1966 & 0,000 & Valid \\
Sumber: Data & primer diolah (2021) & &
\end{tabular}

Berdasarkan tabel 4 di atas menunjukkan item instrumen variabel lokasi (X3) dinyatakan valid karena $r_{\text {hitung }}>r_{\text {tabel }}$ dan nilai signifikansi $<0,05$ sehingga semua item yang dipakai pada variabel lokasi (X3) dinyatakan valid (sah).

Tabel 5. Hasil Uji Validitas Variabel Kepuasan Konsumen

\begin{tabular}{ccccc}
\hline Butir & $\mathbf{r}_{\text {hitung }}$ & $\mathbf{r}_{\text {tabel }}$ & Signifikansi & Keterangan \\
\hline Y.1 & 0,857 & 0,1966 & 0,000 & Valid \\
Y.2 & 0,964 & 0,1966 & 0,000 & Valid \\
Y.3 & 0,951 & 0,1966 & 0,000 & Valid \\
\hline
\end{tabular}


Berdasarkan tabel 5 diatas menunjukkan item instrumen variabel kepuasan konsumen $(\mathrm{Y})$ dinyatakan valid karena $r_{\text {hitung }}>r_{\text {tabel }}$ dan nilai signifikansi $<0,05$ sehingga semua item yang dipakai pada variabel kepuasan konsumen (Y) dinyatakan valid (sah).

Tabel 6. Hasil Uji Reliabilitas Variabel Penelitian

\begin{tabular}{lccc}
\hline \multicolumn{1}{c}{ Variabel } & Cronbach's alpha & Batas Penerimaan & Keterangan \\
\hline Kualitas pelayanan & 0,837 & 0,60 & Reliabel \\
Harga & 0,612 & 0,60 & Reliabel \\
Lokasi & 0,611 & 0,60 & Reliabel \\
Kepuasan konsumen & 0,915 & 0,60 & Reliabel \\
\hline Sumber: Data primer diolah (2021) & & &
\end{tabular}

Berdasarkan tabel 6 diatas dapat dijelaskan bahwa nilai cronbach alpha $>0,60$ sehingga semua variabel dinyatakan reliabel.

\section{Uji Asumsi Klasik}

\section{Uji Multikolinieritas}

Menurut Ghozali dalam (Yani Dahliani et al, 2020: 1017), untuk mendeteksi model regresi bebas dari multikolinieritas dapat dilihat dari nilai tolerance $>0,1$ dan nilai VIF $<10$.

\begin{tabular}{cccc}
\multicolumn{4}{c}{ Tabel 7. Hasil Uji Multikolinieritas } \\
\hline No & Variabel Bebas & Tolerance & VIF \\
\hline 1 & Kualitas Pelayanan & 0,841 & 1,189 \\
2 & Harga & 0,799 & 1,251 \\
3 & Lokasi & 0,891 & 1,122 \\
Sumber: Data primer diolah (2021) & &
\end{tabular}

Berdasarkan tabel 7 diatas dapat diketahui bahwa nilai tolerance $>0,1$ dan VIF $<10$, sehingga model regresi dapat dipakai karena tidak terjadi adanya multikolinieritas.

\section{Uji Heteroskedastisitas}

Menurut Ghozali dalam (Rosdian Widiawati Watung dan Ventje Ilat, 2016:523), uji heteroskedastisitas bertujuan untuk menguji apakah dalam model regresi terjadi ketidaksamaan varian dari residual di satu pengamatan ke pengamatan lain.

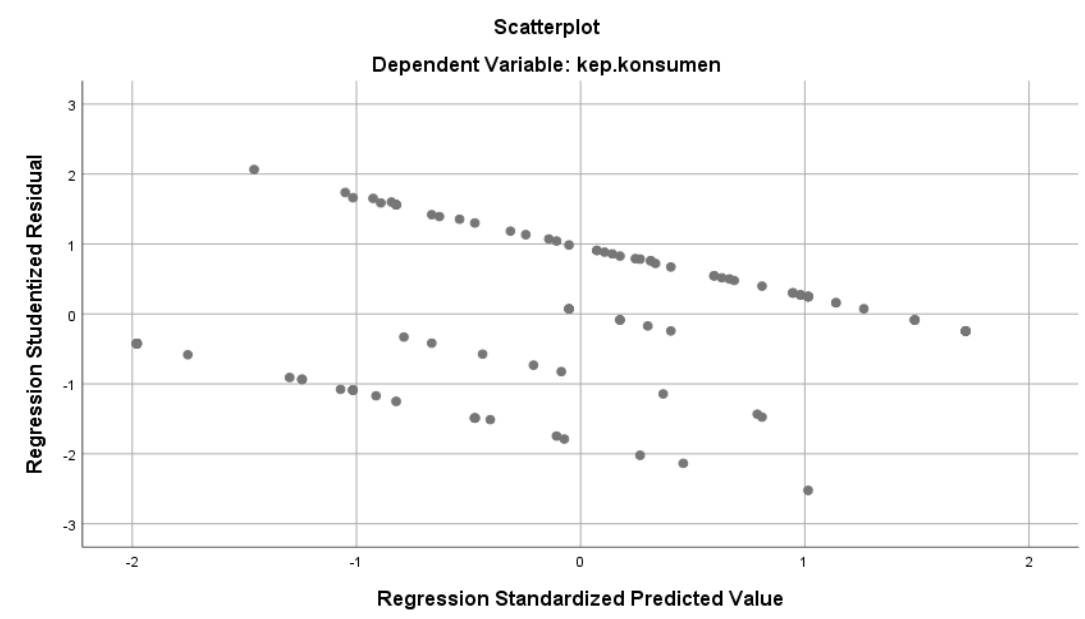

Sumber: Data primer diolah (2021)

Gambar 1. Hasil Uji Heteroskedatisitas 
Berdasarkan gambar di atas menunjukkan bahwa tidak ada pola tertentu seperti titik-titik yang membentuk suatu pola tertentu yang teratur (melebar dan menyempit), tidak terdapat pola yang jelas sehingga dapat disimpulkan bahwa model regresi pada penelitian ini dapat dipakai karena tidak terjadi heteroskedastisitas.

\section{Uji Normalitas}

Menurut Yani Dahliani et al (2020), uji normalitas bertujuan untuk mengetahui apakah masing-masing variabel berdistribusi normal atau tidak. Suatu model regresi dapat memenuhi asumsi normalitas apabila data menyebar di atas garis diagonal dan mengikuti arah garis diagonal.

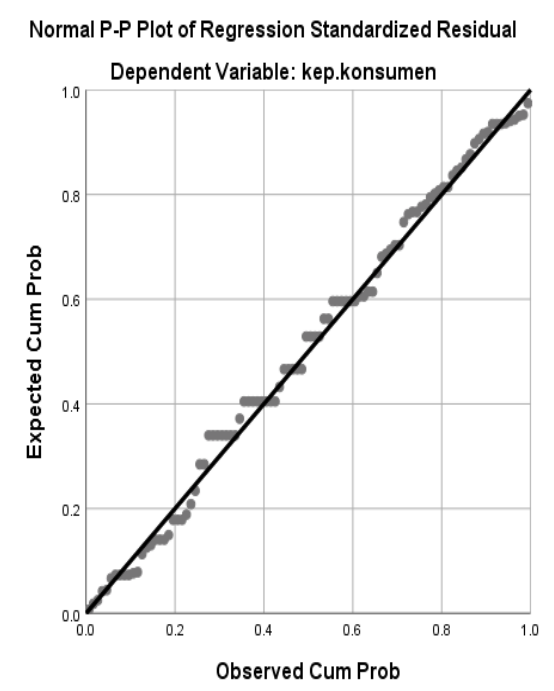

Sumber: Data primer diolah (2021)

Gambar 2. Hasil Uji Normalitas

Berdasarkan gambar 2 dapat diketahui bahwa dat menyebar disekitar garis diagonal dan mengikuti arah garis diagonal, maka model regresi tersebut memenuhi asumsi normalitas.

\section{Uji Regresi Linear Berganda}

Analisa ini digunakan untuk mengetahui apakah terdapat pengaruh dan hubungan antara variabel independen (keragaman produk, kualitas pelayanan, dan store atmosphere) terhadap variabel dependen (keputusan pembelian) pada Cherry Stores Kebumen.

Tabel 8. Hasil Regresi Linear Berganda

\begin{tabular}{|c|c|c|c|c|c|}
\hline \multirow[t]{2}{*}{ Model } & \multicolumn{2}{|c|}{$\begin{array}{c}\text { Unstandardized } \\
\text { Coefficients }\end{array}$} & \multirow{2}{*}{$\begin{array}{c}\begin{array}{c}\text { Standardized } \\
\text { Coefficients }\end{array} \\
\text { Beta }\end{array}$} & \multirow[t]{2}{*}{$\mathbf{t}$} & \multirow[t]{2}{*}{ Sig. } \\
\hline & B & Std. Error & & & \\
\hline (Constant) & 1,021 & 1.460 & & .700 & .486 \\
\hline $\begin{array}{l}\text { Kualitas } \\
\text { pelayanan }\end{array}$ & .173 & .061 & .259 & 2.840 & .006 \\
\hline Harga & .267 & .090 & .277 & 2.963 & .004 \\
\hline Lokasi & .293 & 106 & .245 & 2.771 & .007 \\
\hline
\end{tabular}

Sumber: Data primer diolah (2021) 
Pengaruh Kualitas Pelayanan terhadap Kepuasan Konsumen pada Warung Bakso Lumayan Pak Cipto Karanganyar. Hasil $t$ hitung untuk variabel Kualitas Pelayanan $(\mathrm{t}=$ $2,840)$ lebih besar dari $t$ tabel $(t=1,66088)$ dengan tingkat signifikasi $(\alpha=0,006)$ lebih kecil dari $(a=0,05)$. Berdasarkan hasil tersebut maka berarti bahwa Kualitas Pelayanan berpengaruh signifikan terhadap Kepuasan Konsumen pada Warung Bakso Lumayan Pak Cipto Karanganyar.

Pengaruh Harga terhadap Kepuasan Konsumen pada Warung Bakso Lumayan Pak Cipto Karanganyar. Hasil $t$ hitung untuk variabel Harga $(t=2,963)$ dan $t$ tabel $(t=1,66088)$ dengan tingkat signifikasi $(t=0,004)$ lebih kecil dari $(a=0,05)$ berdasarkan hasil tersebut maka berarti bahwa Harga berpengaruh signifikan terhadap Kepuasan Konsumen pada Warung Bakso Lumayan Pak Cipto Karanganyar.

Pengaruh Lokasi terhadap kepuasan konsumen pada Warung Bakso Lumayan Pak Cipto Karanganyar. Hasil $t$ hitung untuk variabel Lokasi yaitu $(t=2.771)$ lebih besar dari $t$ tabel $(t=1,66088)$ dengan tingkat signifikasi $(t=0,007)$ lebih kecil dari $(\alpha=0,05)$ berdasarkan hasil tersebut maka berarti Lokasi berpengaruh signifikan terhadap Kepuasan Konsumen pada Warung Bakso Lumayan Pak Cipto Karanganyar.

\section{Uji Simultan (Uji F)}

Uji $\mathrm{F}$ digunakan untuk menguji tingkat signifikansi dari pengaru variabel independen (kualitas pelayanan, harga dan lokasi) terhadap variabel dependen (kepuasan konsumen).

Tabel 9. Hasil Hipotesis Uji Simultan (Uji F)

\begin{tabular}{|c|c|c|c|c|c|c|}
\hline \multicolumn{2}{|c|}{ Model } & $\begin{array}{l}\text { Sum of } \\
\text { Squares }\end{array}$ & $\mathrm{df}$ & $\begin{array}{l}\text { Mean } \\
\text { Square }\end{array}$ & $\mathrm{F}$ & Sig \\
\hline \multirow[t]{3}{*}{1} & Regression & 57.244 & 3 & 19.081 & 15.711 & $.000^{b}$ \\
\hline & Residual & 116.596 & 96 & & & \\
\hline & Total & 173.840 & 99 & & & \\
\hline
\end{tabular}

Berdasarkan tabel 9 di atas diperoleh nilai $F_{\text {hitung }}$ sebesar 15.711 dengan tingkat signifikansi

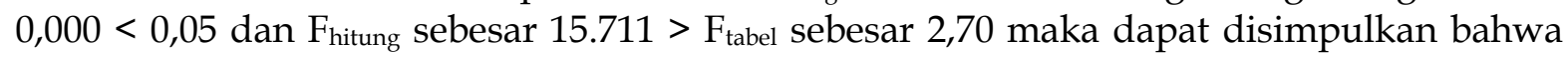
kualitas pelayanan, harga dan lokasi berpengaruh signifikan terhadap kepuasan konsumen pada Warung Bakso Lumayan Pak Cipto Karanganyar secara simultan, maka hipotesis 4 dapat diterima.

\section{Koefisien Determinasi}

Analisis koefisien determinasi digunakan untuk mengetahui besarnya pengaruh variabel independen terhadap variabel dependen secara bersama-sama atau simultan.

Tabel 10. Hasil Uji Koefisien Determinasi

\begin{tabular}{lcccc}
\hline Model & $\mathbf{R}$ & R Square & $\begin{array}{c}\text { Adjusted } \mathbf{R} \\
\text { Square }\end{array}$ & $\begin{array}{c}\text { Std. Error of the } \\
\text { Estimate }\end{array}$ \\
\hline 1 & $.574^{\text {a }}$ & .329 & .308 & 1.102 \\
\hline Sumber: Data primer diolah (2021) & & &
\end{tabular}

Berdasarkan Tabel 10, nilai koefisien determinasi Adjusted yang diperoleh sebesar 0,308 atau (30,8\%). Berdasaarkan hasil tersebut berarti bahwa variabel Kualitas Pelayanan, Harga dan Lokasi berpengaruh terhadap Kepuasan Konsumen pada Warung Bakso Lumayan Pak 
Cipto Karanganyar sebesar $(30,8 \%)$ dan sisanya $(69,2 \%)$ dipengaruhi oleh variabel lain yang tidak digunakan dalam penelitian ini.

\section{Pembahasan}

\section{Pengaruh Kualitas Pelayanan terhadap Kepuuasan Konsumen pada Warung Bakso Lumayan Pak Cipto Karanganyar}

Hipotesis pertama diajukan untuk mengetahui kualitas pelayanan terhadap kepuasan konsumen. Hasil uji $\mathrm{t}$ variabel kualitas pelayanan menunjukkan bahwa $\mathrm{t}$ hitung $(2,840)$ lebih besar dari $t$ tabel $(1,66088)$ dengan tingkat signifikasi $(0,006)$ lebih kecil dari $(\alpha=0,05)$, sehingga hipotesis pertama diterima, yang berarti bahwa kualitas pelayanan berpengaruh signifikan terhadap kepuasan konsumen pada Warung Bakso Lumayan Pak Cipto Karanganyar. Berdasarkan hasil perhitungan tersebut maka dapat disimpulkan bahwa semakin baik kualitas pelayanan (Responsiveness, Reliability, Assurance, Empathy, Tangibles) yang diterapkan dan diimplikasikan maka akan semakin baik pula kepuasan konsumen pada Warung Bakso Lumayan Pak Cipto Karanganyar.

Penelitian ini menemukan hasil yang sama dengan penelitian yang dilakukan oleh Tiyas Windarty dan Mariaty Ibrahim (2017) yang berjudul "Pengaruh kualitas produk dan kualitas pelayanan terhadap kepuasan konsumen produk donut madu Cihanjung Pekanbaru" dengan hasil kualitas pelayanan berpengaruh signifikan terhadap kepuasan konsumen. Sehingga dapat dikatakan bahwa variabel kualitas pelayanan mempunyai pengaruh signifikan dan positif terhadap kepuasan konsumen pada Warung Bakso Lumayan Pak Cipto Karanganyar. Berdasarkan hal ini, perumusan hipotesis pertama yang berbunyi kualitas pelayanan berpengaruh signifikan terhadap kepuasan konsumen pada Warung Bakso Lumayan Pak Cipto Karanganyar" dinyatakan diterima.

\section{Pengaruh Harga terhadap Kepuasan Konsumen pada Warung Bakso Lumayan Pak Cipto Karanganyar}

Hipotesis kedua diajukan untuk mengetahui pengaruh harga terhadap kepuasan konsumen. Hasil uji $t$ variabel harga menunjukkan bahwa thitung $(2,963)$ lebih besar dari t tabel 1.66088 dengan tingkat signifikasi $(0,004)$ lebih kecil dari $(\alpha=0,05)$, sehingga hipotesis kedua diterima, yang berarti bahwa harga berpengaruh signifikan terhadap kepuasan konsumen pada Warung Bakso Lumayan Pak Cipto Karanganyar.

Hal ini berarti setiap kenaikan atau bertambahnya satu satuan pada variabel Harga akan menaikan Kepuasan Konsumen, didukung dengan kualitas pelayanan yang baik, terjangkaunya harga, kesesuaian harga dengan kualitas produk, serta cita rasa bakso yang memuaskan atau kesesuaian harga dengan manfaat sehingga konsumen tidak berpindah ke produk bakso lain. Penelitian ini juga menemukan hasil yang sama seperti penelitian yang dilakukan oleh Rama Joko Darmawan dan Budhi Satrio (2017) yang mengemukakan bahwa harga berpengaruh secara signifikan terhadap tingkat kepuasan konsumen. Sehingga dapat dikatakan bahwa variabel harga mempunyai pengaruh signifikan dan positif terhadap kepuasan konsumen pada Warung Bakso Lumayan Pak Cipto Karanganyar. Berdasarkan hal ini, perumusan hipotesis kedua yang berbunyi harga berpengaruh signifikan terhadap kepuasan konsumen pada Warung Bakso Lumayan Pak Cipto Karanganyar" dinyatakan diterima.

\section{Pengaruh Lokasi terhadap Kepuasan Konsumen pada Warung Bakso Lumayan Pak Cipto Karanganyar}

Hipotesis ketiga diajukan untuk mengetahui lokasi terhadap kepuasan konsumen. Hasil uji t variabel lokasi menunjukkan bahwa t hitung $(2,771)$ lebih besar dari t tabel $(1,66088)$ dengan tingkat signifikasi $(0,007)$ lebih kecil dari $(\alpha=0,05)$, sehingga hipotesis ketiga 
diterima, yang berarti bahwa lokasi berpengaruh signifikan terhadap kepuasan konsumen pada Warung Bakso Lumayan Pak Cipto Karanganyar. Berdasarkan hasil perhitungan tersebut maka dapat disimpulkan bahwa semakin baik lokasi usaha (Keterjangkauan, Kelancaran, Kedekatan dengan kediaman) pada Warung Bakso Lumayan Pak Cipto Karanganyar maka semakin besar pula kepuasan konsumen terhadap pembelian pada Warung Bakso Lumayan Pak Cipto Karanganyar.

Penelitian ini menemukan hasil yang sama dengan penelitian yang dilakukan oleh Rama Joko Darmawan dan Budhi Satrio (2017). Sehingga dapat dikatakan bahwa variabel lokasi mempunyai pengaruh signifikan dan positif terhadap kepuasan konsumen pada Warung Bakso Lumayan Pak Cipto Karanganyar. Berdasarkan hal ini, perumusan hipotesis ketiga yang berbunyi "lokasi berpengaruh signifikan terhadap kepuasan konsumen pada Warung Bakso Lumayan Pak Cipto Karanganyar” dinyatakan diterima.

\section{Penutup}

\section{Simpulan}

a. Kualitas Pelayanan berpengaruh signifikan terhadap Kepuasan Konsumen pada Warung Bakso Lumayan Pak Cipto Karanganyar. Artinya, semakin baik kualitas pelayanan yang diterapkan oleh Warung Bakso Lumayan Pak Cipto Karanganyar maka akan semakin baik pula kepuasan konsumen, begitupun sebaliknya semakin buruk kualitas pelayanan maka kepuasan konsumen pada Warung Bakso Lumayan Pak Cipto Karanganyar semakin rendah.

b. Harga berpengaruh signifikan terhadap Kepuasan Konsumen pada Warung Bakso Lumayan Pak Cipto Karanganyar. Artinya kenaikan atau bertambahnya satu satuan pada variabel Harga akan menaikan Kepuasan Konsumen pada Warung Bakso Lumayan Pak Cipto Karanganyar, didukung dengan kualitas pelayanan yang baik, terjangkaunya harga, kesesuaian harga dengan kualitas produk, serta cita rasa bakso yang memuaskan atau kesesuaian harga dengan manfaat sehingga konsumen tidak berpindah ke produk bakso lain.

c. Lokasi berpengaruh signifikan terhadap kepuasan konsumen pada Warung Bakso Lumayan Pak Cipto Karanganyar. Artinya bahwa semakin baik lokasi usaha maka semakin baik pula kepuasan konsumen pada Warung Bakso Lumayan Pak Cipto Karanganyar begitu pula sebaliknya semakin buruk lokasi usaha pada Warung Bakso Lumayan Pak Cipto Karanganyar maka akan semakin rendahnya tingkat kepuasan konsumen pada Warung Bakso Lumayan Pak Cipto Karanganyar.

d. Kualitas pelayanan, Harga dan Lokasi bersama-sama memiliki pengaruh secara signifikan terhadap Kepuasan konsumen pada Warung Bakso Lumayan Pak Cipto Karanganyar. Pendapat tersebut dihasilkan dari perhitungan F hitung sebesar 15.711 dan lebih besar dari $\mathrm{F}$ tabel yaitu $(\mathrm{F}=2,70)$ dengan tingkat signifikasi 0,000 lebih kecil dari $(a=0,05)$.

e. Koefisien deteminasi $\left(\boldsymbol{R}^{2}\right)$ dengan nilai Adjusted R Square sebesar 0,308 maka dapat di simpulkan bahwa kualitas pelayanan, harga dan lokasi memiliki pengaruh $(30,8 \%)$ terhadap kepuasan konsumen, sedangkan sisanya yaitu sebesar 69,2\% dipengaruhi oleh varibael lain yang tidak terdapat pada penelitian ini.

\section{Referensi}

Amanah, D. (2010). Pengaruh harga dan kualitas produk terhadap kepuasan konsumen pada majestyk bakery \& cake shop cabang HM Yamin Medan. Jurnal Keuangan \& Bisnis, 2(1), 71-87. 
Darmawan, R. J., \& Satrio, B. (2017). Pengaruh Harga, Kualitas Pelayanan, Dan Lokasi Terhadap Kepuasan Konsumen Pada Apotek Takavi. Jurnal Ilmu dan Riset Manajemen (JIRM), 6(8).

Guntur, E. M. (2010). Transformasi Manajemen Pemasaran. Jakarta: Sagung Seto.

Hardiansyah. (2011). Kualitas Pelayanan Publik. Yogyakarta: Gava Media.

Hurriyati, R. (2015). Bauran Pemasaran dan Loyalitas Konsumen. Bandung: CV. Alfabeta.

Kotler, P., \& Armstrong, G. (2010). Principles of Marketing. edisi 13. Pearson. United States of America.

Kotler, P., \& Keller, K. L. (2009). Manajemen Pemasaran, edisi 13 jilid 1 dan 2. Jakarta. Penerbit Erlangga.

Machfoedz, M. (2010). Komunikasi Pemasaran Modern Cetakan Pertama. Yogyakarta: Cakra Ilmu.

Manurung, D. (2009). Pengaruh Kepuasan Konsumen Terhadap Loyalitas Merek pada Pengguna Kartu Pra-Bayar Simpati. Skripsi. Jurnal Fakultas Psikologi Universitas Sumatera Utara. Medan.

Priansa, J. (2017). Perilaku Konsumen Dalam Pesaingan Bisnis Kontemporer. Bandung: Alfabeta.

Santoso, A., \& Widowati, S. (2011). Pengaruh Kualitas Pelayanan, Fasilitas dan Lokasi terhadap Keputusan Pembelian. Jurnal Dinamika Sosial Budaya, 13(2), 179-190.

Situmeang, L. S. (2017). Pengaruh Kualitas Pelayanan, Harga, dan Lokasi terhadap Kepuasan Konsumen pada rumah makan hot plate Medan. Skripsi. Jurnal Fakultas Ekonomi Dan Bisnis Islam. Universitas Islam Negeri Sumatera Utara.

Sunyoto, D. (2015). Perilaku Konsumen dan Pemasaran. CAPS: Yogyakarta.

Tias Windarti, Mariaty Ibrahim. 2017. Pengaruh Kualitas Produk dan Kualitas Pelayanan terhadap Kepuasan Konsumen Produk Donat Madu Cihanjuang-Pekanbaru. Jurnal Administrasi Bisnis FISIP, 4(2).

Tjiptono, F. (2005). Pemasaran Jasa, Malang: Bayumedia Publishing.

Tjiptono, F. (2014), Pemasaran Jasa - Prinsip, Penerapan, dan Penelitian, Yogyakarta: Andi.

Wulandari, N. (2013). Analisis Pengaruh Kualitas Produk, Kualitas Pelayanan, dan Lokasi terhadap Kepuasan Konsumen Kopikita Semarang. Skripsi. Universitas Diponegoro Semarang. 